\title{
A Study of Chinese Piano Works from the Perspective of Ethnomusicology
}

\author{
Huan Bi \\ College of Art, Yangtze University, Jingzhou, Hubei, China
}

\begin{abstract}
Chinese piano works are closely related to folk music. In piano education, Chinese piano works should be analyzed from the perspective of ethnomusicology to guide the students to accurately understand and feel the characteristics and charm of national music culture. This paper probes into the unique national cultural characteristics, national musical styles and musical aesthetic characteristics of Chinese piano works.
\end{abstract}

Keywords: folk music; Chinese piano works; musical genre; musical aesthetic characteristics

\section{Introduction}

After piano was introduced into China, it was integrated with folk music and gradually formed the unique Chinese piano works in the world. Compared with western piano works, Chinese piano works have many differences in music creation, music characteristics and music aesthetics, which have strong connotation of national music. Therefore, in the teaching of Chinese piano works, appreciation and analysis should be carried out on the basis of ethnomusicology. Only in this way can the unique musical charm of Chinese piano works be thoroughly and accurately analyzed.

\section{The Unique National Cultural Characteristics of Chinese Piano Works}

Chinese piano works integrate Chinese traditional culture and folk music elements, which is a reference and a recreation of western piano culture. Chinese piano works are unique among the world's piano works, with strong identification and obvious characteristics of national music culture. Therefore, when creating Chinese piano works, it is necessary to follow the characteristics of its national culture. In general, the unique national creation characteristics of Chinese piano works are mainly reflected in three aspects: the adaptation of folk music works, the innovation based on the Chinese national melody system, and the combination of western creative techniques and the cultural connotation of Chinese folk music. The adaptation of folk music works is based on the piano as a new medium, drawing on the essence of traditional Chinese music and showing the charm of traditional music works. For example, "two springs reflecting the moon" by Chu Wanghua and "liuyang river" by Wang Jianzhong. Based on the traditional folk music system as the core, the innovation of the traditional folk music system is carried out with modern methods, so as to create Chinese piano works more in line with modern aesthetics. For example, Wang Danhong's "oriental horizon" is a representative work. The combination of western creative techniques and Chinese traditional folk music cultural connotation is to infiltrate the traditional music connotation into the western piano creative techniques. Expressing the core content of eastern music by means of western music creation can better reflect the charm of the fusion of Chinese and western music culture. For example, Wang Jianzhong's "scherzo" is one of the best.

Copyright (C) 2020 by author(s) and Frontier Scientific Research Publishing Inc.

This work is licensed under the Creative Commons Attribution International License (CC BY 4.0).

http://creativecommons.org/licenses/by/4.0/ 


\section{The Penetration and Embodiment of Different Genres of Folk Music in Chinese Piano}

Works

Chinese traditional folk music styles are diverse and have been permeated and embodied in Chinese piano works. Through different genres of piano works, can also feel different national characteristics.

\subsection{Folk song}

As an important part of Chinese traditional music, folk songs are not only rooted in the folk music culture of different nationalities, but also the main manifestation of the traditional culture of different regions. Because of the importance of folk songs in Chinese traditional folk music, the adaptation of folk songs has become a major feature of Chinese piano works. Since piano was introduced into China, many composers have drawn inspiration and national elements from folk songs and created a large number of excellent piano works with unique Chinese cultural characteristics. These piano works not only expand the catalogue of Chinese piano works, but also promote the continuous innovation of their creative techniques, reflecting the distinctive characteristics of the national style. When composers create piano works, they usually choose the folk songs that people are familiar with. Therefore, folk songs of different places are reflected to different degrees in Chinese piano works. This has gradually formed a relatively complete system for the creation of piano works adapted from folk songs and promoted the synchronous development of folk music art and piano music art in China. Take the famous Chinese composer Huang Huwei as an example. Huang Huwei was born in Sichuan and has profound attainments in Sichuan folk songs. Many of his Chinese piano works contain elements of Sichuan folk songs. "Painting of bashu" is a piano suite composed by Huang Huwei with six Sichuan folk songs in 1956. In Pujiang folk song "song mowing the lawn", Maoxian county Tibetan folk songs of "snow on the mountain", "like a flower", Jiangyou folk song "river see elder sister wearing green", Aba Tibetan folk songs and dances, Sichuan han folk song "the river rose water", the Aba Tibetan folk dance of reference and created again, he produced the "morning song, the hollow echo, lyric tune, string, spring of Argo jiao, the Aba night will" and so on six piano suite. Each of the pieces in the suite is like a landscape painting, expressing praise for the natural scenery of bashanshushui and love for the people of his hometown.

\subsection{The national instrumental music}

Ethnic instrumental music is an integral part of traditional Chinese music, which is usually divided into "eight tones". National instrumental music has a long history, which contains rich traditional cultural connotation, and has distinct characteristics of traditional culture. Chinese national instrumental music is unique and provides abundant resources for the creation of Chinese piano works. It is common for Chinese piano works to learn from and adapt traditional instrumental music, such as "song of the phoenix", "house of flying daggers" and "three stanzas of plum blossoms". When the composer is adapting, he will keep the original music to the greatest extent and make appropriate adjustments according to the characteristics of the piano. For example, changing harmony, adjusting rhythm, changing structure, etc. This can not only ensure the piano music harmonious and beautiful, but also can fully show the national style of the piano music.

When ethnic instrumental music is integrated into Chinese piano works, it is necessary to highlight the unique timbre of ethnic instrumental music from the perspective of folk songs, so as to create piano works with unique characteristics of Chinese traditional music culture. Most ethnic instrumental music is embodied in Chinese piano works, among which the guqin, guzheng, pipa, xiao and so on are more common. Chinese piano music has a variety of imitations of national instrumental music. A piece of music often imitates a variety of national instrumental music, which fully demonstrates the organic combination of piano and national instrumental music. For example, Li Yinghai's piano song "setting sun xiao gu" borrows the unique timbre of a large number of national instrumental music, and uses the piano to imitate the timbre of national instruments such as xiao, pipa, guzheng and guqin to construct a harmonious and unified piano playing melody. 
The reference and fusion of national instrumental music in "setting sun xiao gu" is not only reflected in the imitation of timbre, but also in the aesthetic thought. The melodious piano painted a landscape painting under the setting sun, expressing the leisurely atmosphere of the mood. In addition, Chinese piano music can not only imitate the timbre of national instrumental music, but also imitate the performance techniques of national instrumental music, which deeply demonstrates the charm of traditional Chinese music culture. For example, Wang Jianzhong's famous piano piece "three stanza of plum blossoms" imitates the "sanyin" played by the guqin by using the octave chord adjutant in the bass, which truly reproduces the essence of "three stanza of plum blossoms" and fully displays the lofty, clean and upright artistic mood of plum blossoms.

\subsection{Opera}

As the treasure of traditional folk music, opera has collected many excellent achievements and musical elements. Opera is a unique type of music in the world and an important source of Chinese piano works. The reference and application of opera music elements in Chinese piano works are mainly reflected in the aspects of tone, board style, rhythm, etc. For example, Cao Guangping's "9 piano songs imitating the high-tone style of sichuan opera" is exactly the combination of elements of Sichuan opera and piano creation techniques to reproduce the musical charm of Sichuan opera by piano.

\subsection{Ritual music}

Ritual music is a product of Chinese religious origin, with a very strong religious color. Most of them are solemn, solemn, quiet and so on, which is very consistent with the characteristics of piano music itself. Composers often use ritual music, especially elements related to buddhist music, for their piano compositions. For example, the fourth song of "tao sheng" in Wang Lisan's piano suite "kuiyi painting of dongshan" comes from the buddhist music tunes "xianghua qing" and "deng baodian".

\section{The Aesthetic Characteristics of Chinese Piano Works}

\subsection{Modal sound structure}

The imperial melody system is the basic mode of Chinese folk music, which is mainly composed of gong, shang, jiao, zheng and yu. It is an important feature of traditional folk music as well as the main aesthetic feature of traditional Chinese music. In Chinese piano music, the continuation and expression of this aesthetic feature is very common. Most of the Chinese piano works form a tonal structure with five tones as the backbone, thus highlighting the distinctive characteristics of traditional Chinese folk music. For example, He Lvting's piano piece "shepherd's piccolo" is a typical tonal structure. The counterpoint processing of two-part and five-tone tunes makes the tonal structure of the whole piece very characteristic of traditional folk music, highlighting the pentatonic tonal rhythmic structure, making its melody more characteristic of traditional Chinese folk music.

\subsection{Linear musical thinking}

The creation of traditional Chinese folk music is mostly embodied in linear musical thinking, which is closely related to the characteristics of Chinese traditional culture and the aesthetics of traditional music. Compared with the polyphonic music of western piano works, Chinese piano music is relatively simple, which is another aesthetic expression. Western music is closely related to religion, and religion has a profound influence on music. The linear thinking of Chinese traditional music is influenced by Confucianism, Buddhism and Taoism philosophy as well as political background. In the creation of Chinese piano works, linear music thinking is reflected in many piano works. For example, Wang Jianzhong's "three stanza of plum blossoms" that based on the guqin, is a typical linear melody, which is smooth and perfect. 
4.3The form is symmetrical to the rhythm

Both the form structure and rhythm of traditional music emphasize balance and symmetry, which is deeply influenced by the Confucian doctrine of the mean, and is also an important expression of traditional Chinese philosophy. In the creation of Chinese piano works, this characteristic has been continued, fully reflecting the essence and characteristics of Chinese traditional music. For example, the piano music "yangguan Triassic" adopts the overlapping structure, and the rhythm varies from loose - slow - fast - fast - slow - loose. Both the structure and the rhythm are very symmetrical.

\section{Conclusions}

Creation and appreciation of Chinese piano works is inseparable from the ethnic music. Only deep analyze the characteristics and connotation of ethnic music, can truly create excellent Chinese piano works. In the piano education, especially focus on the characteristics of works of nationalization, the traditional music genre and the characteristics of music aesthetics.

\section{Conflicts of Interest}

The author declares no conflicts of interest regarding the publication of this paper.

\section{References}

[1] Xie H.Y. (2019). Diversified Development Path of Chinese Contemporary PianoMusic. Journal of Suzhou Institute of Education, 22(04): 52-54.

[2] Zeng X. (2012). Interpretation of Chinese Piano Works from the Perspective of Ethnomusicology. Sichuan Drama, 5, 111-112.

[3] Gao Y.H. (2016). A Study on the National Style of Chinese Piano Works. Northern Music, 36(21): 22-22.

[4] Li Z.Y. (2018). A Study on the National Development of Piano Education in China. Northern Music, 38(6): 136137.

[5] Yang L. (2018). On the Value of Learning Chinese Piano Works. Art Evaluation, 573(22): 59-60. 